\title{
Multilingualism, Multi-competence and (Limits to) the Interaction Between Language Systems ${ }^{1}$
}

David Singleton

Trinity College Dublin / University of Pannonia

dsnglton@tcd.ie

\begin{abstract}
This article addresses the proposition that all talk whatsoever of bounds between language-varieties in the mind should be abandoned. This abandonment of boundaries is a standard view in respect of the semantic or conceptual dimensions of language. The tendency does not, however, stop there; being called into question is the whole notion that languages in the mind are bounded entities in any of their aspects. The response offered here to such a position is that language knowledge in the mind is all its aspects, in fact, highly differentiated, and that this differentiation broadly follows the lines recognized by the traditional conception which draws (always, of course, permeable) lines between languages. Evidence is adduced in favour of this latter view from a number of areas, including language loss and recovery, bilingual/multilingual development and communication and the affective dimension of language differentiation.
\end{abstract}

Keywords: Multilingualism; Multi-competence; Language Development; Mental Representation

\section{Introductory}

Multi-competence is the brain-child of Vivian Cook, whose current basic perspective (Cook, 2016 ) is that multi-competence refers to an overarching, overall system discoverable in any mind or community that uses more than one language. This seems unexceptionable, but it appears that some multi-competence enthusiasts - and they are by no means alone - are tempted to adopt a line of discourse which can be interpreted as postulating a degree of unitariness of language knowledge that does not square with the conception of how language has usually been seen as operating in the mind. 
The abandonment of the notion of boundaries differentiating languages in the mind is quite a standard view in respect of the semantic or conceptual levels of language (Mackenzie, 2016), and the common assumption is that for all language-varieties known by users of two or more languages there is a common underlying conceptual base (Kecskes \& Papp, 2000). Athanasoupoulos (2016) in this context discusses the many influential accounts of the mental architecture of multilingualism - particularly amongst psycholinguists - which assume equivalence, fusion, and language-neutrality at the conceptual level (see e.g. De Groot, 1992; Costa, 2005; Kroll \& Stewart, 1994). He goes on to speak of the need to reexamine this notion of a common conceptual base relating to the languages of multilinguals. Citing Pavlenko and Jarvis (Pavlenko, 2005; Jarvis \& Pavlenko, 2008), he points out that (i) most lexical units that are considered 'translation-equivalents' across languages are not in fact characterized by the same conceptual representation, even when they denote concrete entities (Ameel et al., 2005), and (ii) there is increasing evidence from bilingual cognition research of systematic cross-linguistic variation in the conceptual representation of a range of different domains of experience. He concludes that learning a new language necessitates creating new concepts as well as recalibrating existing concepts.

The claim that languages are not differentiated extends, however, beyond the conceptual level. Researchers of diverse theoretical stances are increasingly tending to question the notion that individual languages are genuinely individuated (e.g. De Bot, 2016; De Bot, Lowie \& Verspoor, 2007; Harris, 1998; Toolan, 2008; Vaid \& Meuter, 2016). The response offered in this article is that knowledge of languages in the mind is in all its aspects, in fact, highly differentiated, and that such differentiation broadly follows the lines recognized by the traditional boundaries between languages (which are always, of course, crossable and permeable). Those of us who hold this view would add the claim that only by recognizing such lines of demarcation can we explain a very large number of phenomena relating to multiple language use, including everyday bilingual and multilingual communication.

\section{Evidence against unboundedness}

This section brings together a range of evidence from bilingual and multilingual experience supporting the position that language-varieties in the mind are differentiated. The first 
subsection refers to the fact that when the use of languages is lost (as a result, for example, of stroke), the use of the languages in question is often recovered language by language. It also adverts to the situation where a language disorder may affect one of a multilingual's languages without affecting the others. The second subsection summarizes some of the clear evidence of the separate early development of languages in multilinguals. The final part of the section concerns the phenomenon of multilinguals' keeping their languages apart, relating examples of failure to comprehend utterance in well-known but unexpected languages and to the privileging of particular languages in interlingual relationships.

\subsection{Sequential recovery of languages and non-parallel aphasia}

One kind of evidence against the idea that languages in the mind are unbounded lies in the selective and sequential recovery of language varieties lost as a result of brain damage. These patterns of selective recovery do not necessarily relate to distinct neural representations of the different languages, but may have to do with damage to control mechanisms located in the prefrontal cortex that activate the target language and inhibit the non-target language (see e.g. Abutalebi 2008), in other words, distinguish between different languages. There is also some mysterious but intriguing evidence from non-parallel aphasia (see, e.g., Fabbro 1999, Chapters 12-16), an example of which is to be found below.

In relation to sequential recovery of lost languages, Whitaker $(1978$, p. 27) tells of the case of an English Classics scholar, who, having lost the ability to use all his languages, recovered first Ancient Greek, then Latin, then French and finally English (his L1). Grosjean (1982, p. 260) writes of a native speaker of Swiss German (which is, of course, markedly different from Standard German) who recovered first French and later Standard High German, but who never recovered his native variety. Fabbro (2002, p. 204), for his part, retails the report of an Italian native speaker of Veronese (a variant of Venetian, structurally and lexically different from Standard Italian), who had exclusively used Veronese in her everyday life, except for a few rare words of Italian, but who, following a brain injury, communicated exclusively in Standard Italian. Her condition subsequently improved to the point where she could understand Veronese, but she continued to make productive use of only Standard Italian. A more recent case is that of Jürg Schwyter (Schwyter, 2011), who, following a stroke, lost the use of every one of his languages. He recovered receptive capacities in most 
of them (Standard German, English, Italian and French), but recovered full productive use only of his mother tongue, Swiss German, and his main professional language, English.

As for non-parallel aphasia, Paradis and Goldblum (1989) report the case of a trilingual subject who was a native speaker of Gujarati, which was the language he mainly used with his family. The person in question resided in Madagascar, and so had additionally acquired Malagasy. He had also learned French at school, and used this language in his professional activities. Following a neurosurgical operation, he evidenced disorders typifying Broca's aphasia in Gujarati but no deficits in his other languages. Two years later he had fully recovered Gujarati but had difficulties with Malagasy in terms of verbal fluency and syntactic comprehension. Four years after the operation no disorder was detected in any of his languages.

These cases of selective recovery and non-parallel aphasia point to the notion that each language in the mind is bounded, not of course in terms of physiological separation, but in terms of having its own processing dynamic, in other words having a degree of, as it were, autonomy of developmental individuality.

\subsection{Separate early development of languages}

In respect of early bilingual development, the individuality of the progress of each language is indicated, for example, by a number of studies (Schelleter, Sinka \& Garman, 1997; Sinka and Schelleter, 1998; Sinka, Garman and Schelleter, 2000) which looked at two children acquiring, respectively, Latvian and English and German and English. Latvian and German are both highly inflected languages whereas English, of course, is not a very inflected language. The researchers found evidence of the development of functional categories in Latvian and German from the earliest stages, but not in English, from which they concluded that the nature of Latvian and German input is rich enough to trigger early functional category development, whereas the English input is not. The strong implication of these findings is that the languages acquired by a simultaneous bi-/multilingual develop separately. The question, however, of whether this is in fact the case from the very earliest stages of acquisition has been quite a controversial one. 
One much-cited view is that the simultaneous bi-/multilingual begins with a single language system and that his/her languages separate only at a later stage (e.g. Volterra \& Taeschner, 1978; see discussion in Clark, 2016, p. 386ff.). This standpoint suggests that simultaneous bi/multilinguals begin with a single language system, a single fused linguistic representation, and that only around the age of three years do they begin to differentiate their languages (see e.g. Pettito et al., 2001, p. 455). Language mixing certainly does manifest itself in the language use of young multilinguals, and much of this mixing undoubtedly happens because children may know an expression in one language for which they have no equivalent in their other languages. Nicoladis and Secco (2000), for example, found that about $90 \%$ of the mixing that they observed in very young bilinguals was due to their lexical gaps in one language or another. Zhang's (2006) work on sibling-sibling interaction between two Chinese-English bilingual children illustrated this. For instance, the Chinese expressions kaoya ('roast duck') and fu-lu ('pickle made from soya beans') were used by the children in English matrix utterances because the English translation-equivalents were unknown (and in the latter case non-existent).

This is an entirely natural communication strategy - used by older children, adolescents and adults as well as by very young bilinguals. Of itself it says nothing about the issue of the separation or integration of a young multilingual's languages. There is, in fact, relatively little interaction between multiple languages at a morpho-syntactic level, and lexical mixing is in general not all that frequent. The bilingual child, in other words, develops in each language in a way similar to monolinguals in the languages in question and is able to make appropriate language choices with different interlocutors (De Houwer 1990). What is more, children use language-specific word ordering at the stage of two-word utterances and complex sentences (e.g. Meisel 1989). Quay (1995) shows in her research the falsity of the notion that the multilingual's lexicon is systematically distributed across languages. She, accordingly, strongly disputes the claim that there is a stage at which the multilingual has just one lexical item in one or other language for a particular meaning.

The evidence seems to show that bi-/multilingual children generally keep their languages apart when using them and are remarkably adept - even at a very early age (see e.g. Genesee, Nicoladis \& Paradis, 1995; Nicoladis 1998) - at making the right decisions as to 
which language to speak to whom. Bilinguals' awareness of their bilingualism begins to develop during their second year of life, possibly as early as 1 year; 7 months as is shown by their first metalinguistic utterances referring to their bilingualism (Meisel, 2006). Where languages are mixed, the mixing in question again seems to evidence an awareness - again from an early age - of dual/multiple language competencies on the part of the interlocutors in question (see e.g. Lanza, 1997). De Houwer has succinctly summed up the situation as follows.

Like monolingual children, bilingual children pay a lot of attention to the input they receive. They soon notice that this input differs depending on who is talking and in what situation someone is talking. Just like monolingual children, bilingual children attempt to talk like the people around them. Because of the bilingual situation, however, the bilingual child has more options than the monolingual one ... [A]t a very young age bilingual children are skilled conversationalists who easily switch languages. (De Houwer, 1995, p. 248)

\subsection{Separation of languages in bi-/multilingual interaction generally}

In their normal functioning, multilinguals, adults no less than children, are very attentive in their use or non-use of specific languages to the competencies of their interlocutors. This is clearly a necessary condition of successful communication. The bounds of a language in the language user's mind are thus set to an extent by the limits of intelligibility.

On the subject of intelligibility, an interesting message comes out of a story e-mailed to me some years ago by the Finnish psychologist, Elizabet Service, about an experience her multilingual sister had in France. I have cited it in a number of publications to illustrate various arguments, but it seems especially relevant in the current context:

My sister, while studying in France was once addressed on the street in Finnish. Only after several attempts by the speaker did she understand her own native language, the point being that she was expecting French. (Service, personal correspondence) 
Service goes on to relate similar episodes in her own life with her L2, English, a language she speaks to a very high level of proficiency:

I have had a very similar experience trying to make Finnish out of something that was easy enough to understand when I realised it was English. (Service, personal correspondence)

This story shows that it is possible for a person not to understand a language in which he/she is highly proficient - including his/her mother tongue - if he/she is not expecting to encounter it. Such evidence suggests that the language in question - as an entire system can be set at a very low level of activation, a radically lower, comprehension-preventing, level of activation than the language(s) one is expecting to encounter. If it is possible for the mind to select a language to render "dormant" in this fashion, as opposed to another language/other languages rendered "ready for action", this clearly speaks volumes about differentiation of languages in the mind.

Especially interesting in this connection is the case of interlingual couples and families (see Singleton \& Pfenninger, 2018). Often two people who get involved with each other and who speak different languages opt for one language as the "glue" of their relationship (Piller, 2002), as their "language of the heart" (Dewaele \& Salomidou, 2017). This language is then set apart from other languages in their repertoire by strong, affective factors. Piller found that many couples perceive their private language as the foundation of their relationship:

[...] we were both happy then that we could speak German, and our relationship started with drinking coffee and speaking, and so speaking was very important to us and whenever we are having a serious conversation, it really needs to be in German, otherwise it doesn't go well, and it doesn't feel right (Piller, 2002, p. 222; cf. Piller, 2001).

Usually the language in question is the $\mathrm{L} 1$ of one of the couple, but not always! 
In this connection, I should like to refer to an interesting case I came across quite recently, and who kindly gave me permission to talk about them in public in a research context. The couple, let call us call them Solange and Jan, met in France, where Solange grew up; Jan is Dutch. They have used English with each other from the start of their relationship. They are now married and living in the Netherlands and they both now have a good command of each other's language, but they continue to retain English as their "language of the heart" for their private conversations. They have a three-year old daughter with whom Solange communicates in French and Jan in Dutch. The common language of the household is sometimes Dutch and sometimes French. The daughter does not yet know English and makes fun of her parents when she hears them speak their language of intimacy. The differentiation of usage of the languages is thus crystal-clear:

Solange to daughter: French;

Jan to daughter: Dutch;

Solange to Jan to Solange (family matters): French/Dutch;

Solange to Jan to Solange (private couple matters): English.

It would appear that this is anything but a "mish-mash". It seems that the language bounds in each language user's mind are in this case related to the pattern agreed upon for French and Dutch and by the role of English as the couple's language of intimacy. The intelligibility factor comes into the picture, though, in that English is (from the parents' point of view happily) unintelligible to the daughter. This latter situation will no doubt change with time. We shall return to the emotional dimension of language differentiation in the next section.

\section{More on "mish-mash"}

We noted earlier the manner in which and the grounds on which Athanasoupoulos (2016) rejects the concept of a common underlying, language-neutral conceptual base. An additional argument running counter to the common conceptual base idea is the fact that language-users seem to feel that their 'take' on the world changes as they switch from language to language. An oft-cited adherent to this point of view was the early Latin poet Quintus Ennius, who, according to the report of Aulus Gellius, used to say that, because he functioned in three languages, Greek, Oscan and Latin, he had 'three hearts' ('Quintus 
Ennius tria cordia habere sese dicebat, quod loqui Graece et Osce et Latine sciret'). To bring the discussion closer to our own times, we need to take very seriously the (for good reason) well-worn truism of modern linguistics (see Lyons, 1963, p. 37f.), according to which every language articulates the world uniquely in terms of its various forms and structures and in terms of its concepts and configurations of concepts. (This clearly underlays what Quintus Ennius was talking about!) It patently implies that, in order to fully understand what is being said and written in a given language community and in order to be understood in the relevant language community, a language user needs to make use of the conceptual system specific to the language system in question, which of its nature will be different from those of other languages he/she may know. The very obvious reality of a degree of cross-linguistic conceptual permeability, influence and transfer does not undermine the other reality of this essential differentiation (see Singleton 2003, 2012).

When Quintus Ennius said that because he had three languages he had three hearts, he was referring to three centres of intelligence and thought as well as seats of the emotions. (The Latin word for "heart", cor, has a broader range of meaning than its English "equivalent".) The emotional denotation and connotation was nevertheless included in his claim, and indeed this emotional dimension is increasingly addressed by current research into conceptual divergences amongst the languages of the multilingual mind. Thus, Dewaele (2016) refers to Pavlenko's (2006) account of the feedback that emerged from the (Dewaele and Pavlenko 2001-2003) Bilingualism and Emotion Questionnaire, where she found that almost two-thirds of participants reported feeling like different people when they switched languages. The evidence at the emotional level too, then, favours differentiation between the multilingual's languages.

Finally, let us consider the case where the language user genuinely seems not to know which language an expression he/she is using belongs to, and the implications of such an eventuality. For instance, Singleton's (1987) study reports on Philip, an English-speaking learner of French who also had some remnants of school knowledge of Latin and Irish, plus some colloquial knowledge of Spanish acquired during a three-year sojourn in Spain. When interacting in French, Philip often made use of Frenchified Spanish expressions (e.g. serc for près de, "near" < Sp, cerca), but from his introspections on his use of these forms, it 
emerged that he occasionally did not know whether he had borrowed them from Spanish or from Latin. In general, let it be said, Philip appeared to be acutely self-aware about his strategy of borrowing from Spanish. He commented that he knew Spanish and French to be historically related and remarked that he often deliberately made use of Spanish expressions, pronounced à la française, in order to make good gaps in his French vocabulary. Indeed, it emerged from the analysis of his data that Spanish was the privileged source of transferred expressions in his French.

As for his not knowing whether particular expressions he borrowed had their origins in Latin or in Spanish, given his low proficiency in Spanish and his rather vestigial knowledge of Latin, we should probably not make too much of this - especially since Latin and Spanish, in fact, have many expressions in common. De Angelis (2007, p. 65-67) discusses such learner uncertainties in a similar fashion. She cites a French-Canadian learner of Italian with prior knowledge of Spanish who, when attempting to speak Italian, used the Spanish word for 'table' - mesa - instead of the Italian word tavolo, apparently being under the impression that mesa was Italian. Also cited by De Angelis is an English learner of Spanish with previous knowledge of Italian who was familiar with two words for 'money' - dinero (Spanish) and soldi (Italian) - but could not say which word belonged to which language. De Angelis takes a comparable line with regard to her findings to that proposed above in connection to Philip's case. She proposes that "language tags or cues may have different strength values at different stages of the acquisition process, and strengths may vary depending on changes in language proficiency over time" (De Angelis, 2007, p. 86).

This is an entirely different kind of account from that which dismisses all idea of differentiation in the mind regarding the languages known to an individual. To be noted also is the fact that, in the instances De Angelis cites, the additional languages in question are Spanish and Italian, which, like Latin and Spanish, have lexicons that to an extent resemble each other. Such confusions, one strongly suspects, would have been far less likely if the languages in question had been, for example, Hungarian and Chinese. One clearly must conclude that there are indeed cases, at impoverished levels of proficiency, of multilingual individuals' being confused about which of their languages some of the words and phrases they deploy belong to -especially when the languages concerned are closely related. The 
exigencies of multilingual communication, however, mean that such confusions cannot afford to come anywhere close to being widespread. For multilingual communication to work, the participants in such communication must be constantly sensitive to what will and will not be understood by their interlocutors and must be attentive to navigating amidst the various languages at their disposal adroitly and precisely. Such navigation relies, of course, on the bounds set between these languages in the mind.

\section{Concluding remarks}

In conclusion, I should like to make reference to Werker's work on early bilingualism, which casts an interesting sidelight on the issues discussed above. Werker (2012) sums up the challenges confronting the infant involved in the process of monolingual language development, pointing out that such an infant has to deploy his/her:

perceptual knowledge of the rhythmical properties of the ... language, of the speech sound categories that distinguish one possible word from another, and of the sequences of sounds that are allowable within a word and/or the statistical learning of other cues to segmentation. (Werker, 2012, p. 50)

It is only on this basis, she says, that the child can isolate different words and structures and map them onto meaning.

Turning to the case of the child growing up in an environment involving more than one language, such a child, she goes on to assert, has to master the rhythmical properties, the phonetic categories, the phonotactic regularities, the word order patterns, the lexisconcept configuration and the conceptualization of the world of each language. What is more, the infant bilingual must do this, she states, without interlingual confusion.

The obvious addendum to Werker's account is that what is true for the infant trying to handle more than one language holds true in broad essence for multilinguals of any age! 


\section{Acknowledgments}

I am grateful to Simone E. Pfenninger for her comments and suggestions regarding an earlier version of this article.

\section{References}

Abutalebi, J. (2008). Neural aspects of second language representation and language control. Acta Psychologica 128, 466-478.

Ameel, E., Storms, G., Malt, B. \& Sloman, S. (2005). How bilinguals solve the naming problem. Journal of Memory and Language, 53(1), 60-80.

Athanasoupoulos, P. (2016). Cognitive consequences of multi-competence. In V. Cook \& Li Wei (eds), The Cambridge handbook of linguistic multi-competence (pp. 355-375). Cambridge: Cambridge University Press.

Clark, E.V. (2016). First language acquisition. $3^{\text {rd }}$ Edition. Cambridge: Cambridge University Press.

Cook, V. (2016). Premises of multi-competence. In V. Cook \& Li Wei (eds) The Cambridge handbook of linguistic multi-competence (pp. 1-25). Cambridge: Cambridge University Press.

Costa, A. (2005). Lexical access in bilingual production. In J. F. Kroll and A. M. B. de Groot (eds), Handbook of bilingualism: Psycholinguistic approaches (pp. 308-325). New York: Oxford University Press.

De Angelis, G. (2007). Third or additional language acquisition. Clevedon: Multilingual Matters.

De Bot, K. (2016). Multi-competence and dynamic/complex systems. In V. Cook \& Li Wei (eds), The Cambridge handbook of linguistic multi-competence (pp. 125-141). Cambridge: Cambridge University Press.

De Bot, K., Lowie, W. and Verspoor, M. (2007). A Dynamic Systems Theory approach to second language acquisition. Bilingualism: Language and Cognition, 10(1), 7-21.

De Groot, A. M. B. (1992). Bilingual lexical representation: A closer look at conceptual representations. In R. Frost \& L. Katz (eds.), Orthography, phonology, morphology and meaning (pp. 389-412). Amsterdam: North Holland.

De Houwer, A. (1990). The acquisition of two languages from birth: A case study. Cambridge: Cambridge University Press.

De Houwer, A. (1995). Bilingual language acquisition, in P. Fletcher \& B. MacWhinney (eds), The handbook of child language (pp. 219-250). Malden, MA: Blackwell.

Dewaele, J.-M. (2016). Multi-competence and emotion. In V. Cook \& Li Wei (eds), The Cambridge handbook of linguistic multi-competence (pp. 461-477). Cambridge: Cambridge University Press.

Dewaele, J.-M. \& Pavlenko, A. (2001-2003). Web questionnaire: Bilingualism and emotions. University of London.

Dewaele, J.-M., \& Salomidou, L. (2017). Loving a partner in a foreign language. Journal of Pragmatics, 108, 116-130.

Fabbro, F. (1999). The neurolinguistics of bilingualism: An introduction. Hove: Psychology Press.

Fabbro, F. (2002). The neurolinguistics of L2 users. In V. Cook (ed.), Portraits of the L2 user (pp. 167-195). Clevedon: Multilingual Matters. 
Genesee, F., Nicoladis, E. \& Paradis, J. (1995). Language differentiation in early bilingual development. Journal of Child Language Development 22(3), 611-631.

Grosjean, F. (1982). Life with two languages: An introduction to bilingualism. Cambridge, MA: Harvard University Press.

Harris, R. (1998). An introduction to integrational linguistics. Kidlington: Elsevier.

Jarvis, S. \& Pavlenko, A. (2008). Crosslinguistic influence in language and cognition. New York: Routledge.

Kecskes, I. \& Papp.T. (2000). Foreign language and mother tongue. Mahwah, NJ: Lawrence Erlbaum.

Kroll, J. F. and Stewart, E. (1994). Category interference in translation and picture naming: Evidence for asymmetric connections between bilingual memory representations. Journal of Memory and Language, 33(2), 149-174.

MacKenzie, I. (2016) Multi-competence and English as a lingua franca. In V. Cook \& Li Wei (eds), The Cambridge handbook of linguistic multi-competence (pp. 478-501). Cambridge: Cambridge University Press.

Lanza, E. (1997). Language mixing in infant bilingualism: A sociolinguistic perspective. Oxford: Clarendon Press.

Lyons, J. (1963). Structural semantics: An analysis of part of the vocabulary of Plato. Volume 20 of Publications of the Philological Society. Oxford: Blackwell.

Meisel, J. M. (1989). Early differentiation of languages in bilingual children. In K. Hyltenstam \& L. Obler (eds), Bilingualism across the lifespan: Aspects of acquisition, maturity, and loss (pp. 13-40). Cambridge: Cambridge University Press.

Meisel, J.M. (2006). The bilingual child. In T. K. Bhatia \& W. C. Ritchie (eds), The handbook of bilingualism ( $\mathrm{pp}, 90-113)$. Oxford: Blackwell.

Nicoladis, E. (1998). First clues to the existence of two input languages: Pragmatic and lexical differentiation in a bilingual child. Bilingualism: Language and Cognition, 1(2), 105-116.

Nicoladis, E. \& Secco, G. (2000). The role of a child's productive vocabulary in the language choice of a bilingual family. First Language, 58(1), 3-28.

Paradis, M. \& Goldblum, M. C. (1989). Selective crossed aphasia in a trilingual aphasic patient followed by reciprocal antagonism. Brain and Language, 36, 62-75.

Pavlenko, A. (2005). Bilingualism and thought. In J. F. Kroll and A. M. B. de Groot (eds), Handbook of bilingualism: Psycholinguistic approaches (pp. 433-453). New York: Oxford University Press.

Pettito, L. A., Katerelos, M., Bronna, G., Levy, K. G., Tétreault, K. and Ferraro, V. (2001). Bilingual signed and spoken language acquisition from birth: Implications for the mechanisms underlying early bilingual language acquisition. Journal of Child Language Acquisition, 28(2), 453-496.

Piller, I. (2001). Linguistic intermarriage: Language choice and negotiation of identity. In A. Pavlenko, A. Blackledge, I. Piller, \& M. Teutsch-Dwyer (eds.), Multilingualism, second language learning and gender (pp. 199-230). Mouton de Gruyter, Berlin-New York.

Piller, I. (2002). Bilingual couples talk: The discursive construction of hybridity. Amsterdam: John Benjamins.

Quay, S. (1995). The bilingual lexicon: Implications for studies of language choice. Journal of Child Language, 22(2), 369-387. 
Schelleter, C., Sinka,I. \& Garman, M. (1997). Latvian/English and German/ English bilingual acquisition: new light on Universal Grammar. In Proceedings of the First International Symposium on Bilingualism (pp. 442-452). Vigo: University of Vigo.

Schwyter, J.R. (2011). "Me talk funny": A stroke patient's personal account. English Today, 27(4), 49-52.

Singleton, D. (1987). Mother and other tongue influences on learner French. Studies in Second Language Acquisition, 9(3), 327-345.

Singleton, D. (2003). Perspectives on the multilingual lexicon: A critical synthesis. In J. Cenoz, B. Hufeisen \& U. Jessner (eds), The multilingual lexicon (pp. 167-176). Amsterdam: Kluwer Academic.

Singleton, D. (2012). Multilingual lexical operations: Keeping it all together ... and apart. In J. Cabrelli Amaro, S. Flynn \& J. Rothman (eds), Third language acquisition in adulthood (pp. 95-114). Amsterdam: John Benjamins.

Singleton, D. \& Pfenninger, S.E. (2018). L2 Proficiency as a function of cultural identity in interlingual couples. Theory and Practice of Second Language Acquisition, 4(1), 7-22.

Sinka, I., Garman M. \& Schelleter, C. (2000). Early verbs in bilingual acquisition. Reading Working Papers in Linguistics, 4, 175-187.

Sinka, I and Schelleter, C. (1998). Morphosyntactic development in bilingual children. Journal of Bilingualism, 2(3), 301-326.

Toolan, M. (2008). Introduction: Language teaching and integrational linguistics. In M. Toolan (ed.), Language teaching: Integrational linguistic approaches (pp. 1-23). London: Routledge.

Vaid, J. \& Meuter, R. (2016). Not through a glass darkly: Refocusing the psycholinguistic study of bilingualism through a 'bivocal' lens. In V. Cook \& Li Wei (eds), The Cambridge handbook of linguistic multi-competence (pp. 77-96). Cambridge: Cambridge University Press.

Volterra, V. \& Taeschner, T. (1978). The acquisition and development of language by bilingual children. Journal of Child Language, 5(2), 311-326.

Whitaker, H. (1978). Bilingualism: A neurolinguistics perspective. In W. Ritchie (ed.), Second language acquisition research: Issues and implications (pp. 21-32). New York: Academic Press.

Zhang, H.-Q. (2006). Bilingual sibling interaction: A case study of linguistic features and their social functions. MPhil dissertation. Trinity College Dublin.

\footnotetext{
${ }^{1}$ This article is based on the text of an invited paper delivered to IRAAL in April 2018
} 